\title{
PENINGKATAN HASIL BELAJAR MATEMATIKA MELALUI METODE PEMBELAJARAN JIGSAW DI KELAS VI SDN 06 INDRALAYA UTARA
}

\author{
Rusli Yunus \\ Guru Sekolah Dasar Negeri 06 Indralaya Utara \\ Jalan Palembang-Prabumulih, Desa Payakabung, Kecamatan Indralaya Utara \\ Kabupaten Ogan Ilir, Sumatera Selatan 30662
}

\section{Sur-el: rusliyunus07@gmail.com}

Article info

Article history:

Received: 15-03-2020

Revised : 02-05-2020

Accepted: 26-05-2020

\begin{abstract}
A B S T R A C T
This study aims to improve student learning outcomes using the Jigsaw learning method in Mathematics in class VI. The subjects in this study were sixth grade students of SD Negeri 06 Indralaya Utara, totaling 30 students. This research was conducted in semester ganjil 2019. The research method used was Classroom Action Research (CAR). This Classroom Action Research (CAR) consists of two cycles. Collecting data is done by two techniques, namely observation and test. The results of the study in the first cycle showed completeness of 63.33\% with KKM 65. In the second Cycle, mathematics learning outcomes increased with completeness by $90 \%$. The average grade of 84.6. So, it can be concluded that learning by using the Jigsaw learning method can improve student learning outcomes in mathematics.
\end{abstract}

Keywords:

Mathematic Learning,

Jigsaw

method,Classroom

Action Research

Kata Kunci:

Hasil Belajar,

Matematika, Metode

Jigsaw, Penelitian

Tindakan Kelas
Penelitian ini bertujuan untuk meningkatkan hasil belajar siswa menggunakan metode pembelajaran Jigsaw pada pelajaran Matematika di kelas VI. Subjek dalam penelitian ini adalah siswa kelas VI SD Negeri 06 Indralaya Utara yang berjumlah 30 orang siswa. Penelitian ini dilaksanakan pada semester ganjil 2019. Metode penelitian yang digunakan adalah Penelitian Tindakan Kelas (PTK). PTK ini terdiri dari dua siklus. Pengmpulan data dilakukan dengan dua teknik, yaitu teknik observasi dan tes. Hasil penelitian pada siklus I menunjukkan ketuntasan sebesar 63,33\% dengan KKM 65. Pada Siklus II, hasil belajar matematika meningkat dengan ketuntasan sebesar 90\%. Rata-rata nilai kelas sebesar 84,6. Jadi, dapat disimpulkan bahwa pembelajaran dengan menggunakan metode pembelajaran Jigsaw dapat meningkatkan hasil belajar siswa pada pelajaran matematika.

Direktorat Riset dan Pengabdian Masyarakat Universitas Bina Darma. 


\section{JURNAL ILMIAH \\ BINA EDUKASI \\ ISSN 1979-8598 E-ISSN: 2655-8378 \\ http://journal.binadarma.ac.id/index.php/jurnalbinaedukasi \\ Vol. 13, No. 1, Juni 2020, 16 -- 26}

\section{PENDAHULUAN}

Sekolah merupakan salah satu tempat bagi siswa mendapatkan ilmu secara formal. Sekolah bukan hanya tempat menimba ilmu tetapi juga sebagai tempat berkumpul, bermain dan berbagai keceriaan antara siswa yang satu dengan siswa yang lainnya sehingga terjadi interaksi di dalamnya. Sekolah juga merupakan tempat dimana kegiatan belajar mengajar berlangsung dan tempat terjadinya interaksi antara guru dan murid. Manusia diciptakan oleh Tuhan dengan membawa fitrah yang merdeka, mempunyai hak dan kebebasan yang telah melekat ada dirinya. Oleh karena itu dalam kehidupan, manusia mempunyai hak untuk hidup, hak bersuara, kebebasan mengemukakan pendapat, dan hak yang lainnya selama kebebasan dan hak tersebut tidak bertentangan dengan norma sosial agama.

Begitu juga dalam kegiatan belajar mengajar, dalam hal ini siswa mempunyai hak dan kebebasan untuk bersuara, berpendapat atau berargumen di dalam kelas yang berkaitan dengan materi pelajaran di kelas. Saat berlangsungnya Kegiatan Belajar Mengajar (KBM) seharusnya yang aktif bukanlah gurunya saja, dimana siswa hanya dianggap sebagai suatu benda yang pasif, yang hanya mendengarkan dan mematuhi apa yang disampaikan oleh guru. Tetapi seharusnya dalam proses KBM antara siswa dan guru secara seimbang dan bersama-sama berinteraksi secara aktif, dalam memberi ilmu pengetahuan baik dari guru ke siswa atau sebaliknya dari siswa ke guru dan dapat juga memberi ilmu antar siswa satu ke siswa yang lainnya.

Pembelajaran matematika yang diinginkan adalah model pembelajaran yang dapat membuat siswa terasa mudah dan senang belajar, serta lebih aktif mempelajari pelajaran matematika sehingga penguasaannya dapat lebih optimal. Salah satu model pembelajaran yang dapat diterapkan dalam pelajaran matematika adalah pembelajaran kooperatif. Pembelajaran kooperatif merupakan model pembelajaran yang menekankan pada kegiatan kerjasama dalam kelompok. Dalam pembelajaran kooperatif, siswa terlibat aktif pada proses pembelajaran sehingga memberikan dampak positif terhadap interaksi dan komunikasi yang berkualitas, dapat memotivasi siswa untuk meningkatkan prestasi belajarnya.

Dari KKM yang telah ditentukan yaitu 65, hanya ada 12 siswa yang mampu melampaui KKM dan selebihnya, yaitu 18 siswa belum dapat mencapai KKM. Berkaitan dengan hal tersebut maka diperlukan suatu metode pembelajaran yang mampu memfasilitasi siswa untuk mendapatkan pengalaman belajar, yaitu metode yang memuat pengalaman belajar dan keaktifan siswa dalam kegiatan belajar mengajar. Berdasarkan observasi awal di kelas VI SD Negeri 06 Indralaya Utara, salah satu mata pelajaran yang dianggap sulit bagi siswa adalah pelajaran matematika. Bahkan sebagian siswa memiliki hasil belajar lebih rendah dari standar KKM 65 dari 


\section{JURNAL ILMIAH \\ BINA EDUKASI \\ ISSN 1979-8598 E-ISSN: 2655-8378 \\ http://journal.binadarma.ac.id/index.php/jurnalbinaedukasi \\ Vol. 13, No. 1, Juni 2020, 16 -- 26}

30 siswa, hanya 12 siswa yang mencapai nilai KKM yaitu 40 dan 18 siswa belum mencapai KKM 65 yaitu 60.

Hal ini disebabkan oleh berbagai faktor, antara lain siswa cenderung pasif mengikuti pelajaran matematika, dan lebih senang jika guru hanya menerangkan dan memberi contohcontoh soal dan cara penyelesaian sehingga tidak aktif menyelesaikan soal. Demikian pula saat mengajar, guru lebih cenderung mengajarkan siswa secara klasikal, lebih banyak memberi contoh-contoh soal di papan tulis kemudian siswa menyalin materi sehingga kurang melibatkan siswa, dan jarang memotivasi dan memberi penguatan selama proses pembelajaran matematika sehingga mempengaruhi aktivitas belajar siswa.Pembelajaran kooperatif pada mata pelajaran matematika dipandang sangat baik diterapkan agar siswa belajar secara kelompok, saling bertukar pikiran, sekaligus saling memotivasi dalam mengerjakan soal-soal matematika.

Metode jigsaw menekankan kepada belajar dalam bentuk kelompok yang diawali pembentukan kelompok asal, kemudian setiap anggota kelompok awal bergabung dengan kelompok ahli untuk berdiskusi. Selanjutnya, setiap anggota kelompok kembali kepada kelompoknya masing-masing (kelompok awal) untuk membahas lebih lanjut masalah yang didiskusikan. Melalui metode pembelajaran Jigsaw, proses matematika diharapkan dapat lebih efektif dalam meningkatkan kualitas pembelajaran, aktivitas belajar, dan hasil belajar matematika siswa.

Penelitian serupa juga pernah dilakukan oleh beberapa orang, diantaranya adalah Ristanti (2017) dengan judul "Penerapan Model Pembelajaran Kooperatif Tipe Jigsaw untuk Meningkatkan Motivasi Belajar dan Prestasi Belajar Kompetensi Dasar Persediaan Siswa Kelas XI AK 1 SMK YPE Sawunggalih Tahun Ajaran 2016/2017” dengan hasil penelitiannya (1) penerapan model pembelajaran kooperatif tipe Jigsaw dapat meningkatkan motivasi belajar kompetensi dasar persediaan, hal ini dibuktikan bahwa skor rerata motivasi belajar kompetensi dasar persediaan pada siklus I sebesar $69,44 \%$ dan pada siklus II mencapai 77,89\% atau terjadi peningkatan sebesar 8,45\%; (2) penerapan model pembelajaran kooperatif tipe Jigsaw dapat meningkatkan prestasi belajar kompetensi dasar persediaan, hal ini dibuktikan bahwa nilai ratarata post test pada siklus I sebesar $72,12 \%$ dan post test pada siklus II sebesar $80 \%$ atau terjadi peningkatan sebesar 7,88 \%. Persentase ketuntasan hasil post test siklus I sebesar $50 \%$ dan persentase ketuntasan hasil post test siklus II sebesar 78,12\% atau meningkat sebesar 28,12\%.

Selanjutnya, Nasruddin dan Zainal Abidin (2017) dengan judul "Meningkatkan Hasil Belajar Matematika Melalui Model Pembelajaran Kooperatif Tipe Jigsaw pada Siswa SMP" dengan hasil penelitiannya pelaksanaan model pembelajaran kooperatif tipe Jigsaw dapat meningkatkan hasil belajar siswa dalam mata pelajaran Matematika. Hal ini ditunjukkan oleh nilai setelah tindakan siklus I meningkat dibandingkan dengan tes awal yakni 45,85\% menjadi 65,75 $\%$. Selanjutnya nilai rata-rata siswa setelah tindakan siklus II meningkat dibandingkan dengan 


\section{JURNAL ILMIAH \\ BINA EDUKASI \\ ISSN 1979-8598 E-ISSN: 2655-8378 \\ http://journal.binadarma.ac.id/index.php/jurnalbinaedukasi \\ Vol. 13, No. 1, Juni 2020, 16 -- 26}

nilai rata-rata siswa pada pelaksanaan tindakan siklus I yaitu 65,75\% menjadi 80,60\% dan telah memenuhi indikator kinerja yang telah ditetapkan yaitu $85 \%$ siswa telah mendapat nilai minimal 65.

Kemudian Santoso (2018) dengan judul "Peningkatan Prestasi Belajar Matematika dengan Menggunakan Metode Pembelajaran Kooperatif Model Jigsaw" dengan hasilnya yaitu pembelajaran dengan metode pembelajaran kooperatif model Jigsaw memiliki dampak positif dalam peningkatkan prestasi belajar siswa yang ditandai dengan peningkatan ketuntasan belajar siswa dalam setiap siklus yaitu pada siklus I $67,86 \%$, pada siklus II $82,14 \%$, dan pada siklus III 89,29 \%.Penelitian tindakan kelas ini dapat membuktikan bahwa dengan metode pembelajaran kooperatif model Jigsaw dapat menigkatkan prestasi belajar siswa kelas VII-A SMP Sunan Drajat Sugio.

Berkaitan dengan uraian di atas, peneliti mengkajinya melalui penelitian tindakan kelas dengan judul "Peningkatan Hasil Belajar Matematika melalui Metode Pembelajaran Jigsaw di kelas VI SDN 06 Indralaya Utara". Tujuan yang ingin diharapkan dalam penelitian ini adalah untuk mengetahui peningkatan hasil belajar siswa pada mata pelajaran matematika menggunakan metode pembelajaran Jigsaw. Berdasarkan uraian latar belakang di atas maka rumusan masalah pada penelitian ini adalah bagaimana peningkatan hasil belajar matematika melalui metode pembelajaran Jigsaw di kelas VI SDN 06 Indralaya Utara.

\section{METODOLOGI PENELITIAN}

\subsection{Metode Penelitian}

Penelitian ini merupakan Penelitian Tindakan Kelas (PTK) atau Classroom Action Research (CAR). Penelitian tindakan kelas berasal dari tiga kata yaitu penelitian, tindakan, dan kelas (Aqib, 2009). Penelitian diartikan sebagai kegiatan mencermati suatu objek, menggunakan aturan metodologi tertentu untuk memperoleh data atau informasi yang bermanfaat untuk meningkatkan mutu dari suatu hal yang menarik minat dan penting bagi penelitian. Tindakan diartikan sebagai suatu gerak kegiatan yang sengaja dilakukan dengan tujuan tertentu, yang dalam penelitian ini berbentuk siklus kegiatan. Kelas diartikan sebagai sekelompok siswa yang dalam waktu yang sama menerima pelajaran yang sama dari seorang guru.

Adapun karakteristik dari PTK menurut Sukardi (2007) adalah (1) masalah yang dipecahkan merupakan persoalan yang dihadapi peneliti dalam kehidupan sehari-hari, (2) peneliti memberikan perlakuan yang terencana untuk memecahkan permasalahan, (3) langkah-langkah penelitian yang direncanakan selalu dalam bentuk siklus, tingkatan atau daur yang memungkinkan terjadi kerja kelompok maupun kerja mandiri secara intensif, (4) adanya langkah berpikir reflektif dari peneliti baik sesudah maupun sebelum tindakan. Menurut Soedarsono 


\section{JURNAL ILMIAH \\ BINA EDUKASI \\ ISSN 1979-8598 E-ISSN: 2655-8378 \\ http://journal.binadarma.ac.id/index.php/jurnalbinaedukasi \\ Vol. 13, No. 1, Juni 2020, 16 -- 26}

(2001), karakteristik PTK meliputi Situasional, artinya berkaitan langsung dengan permasalahan, konkret yang dihadapi guru dan siswa di kelas. Kontekstual, artinya upaya pemecahan yang berupa model dan prosedur tindakan tidak lepas dari konteksnya. Kolaboratif, artinya partisipasi, antara guru - siswa dan mungkin asisten yang membantu proses pembelajaran. Self-reflective dan Self-evaluative, artinya pelaksana, pelaku tindakan serta objek yangh dikenai tindakan melakukan refleksi dan evaluasi diri terhadap hasil atau kemajuan yang dicapai. Fleksibel, artinya memberikan sedikit kelonggaran dalam pelaksanaan tanpa melanggar kaidah metodologi ilmiah.

Penelitian Tindakan Kelas ini menggunakan metode pembelajaran Jigsaw dalam proses pembelajaran Matematika di kelas. Adapun langkah-langkah metode pembelajaran Jigsaw adalah sebagai berikut.

a. Guru mengelompokkan siswa ke dalam kelompok kecil sebanyak bagian materi atau subbab yang akan dibahas.

b. Setiap siswa dalam kelompok diberi bagian materi yang berbeda.

c. Anggota kelompok yang berbeda yang telah mempelajari bagian atau sub-bab yang sama bertemu dalam kelompok baru atau disebut sebagai kelompok ahli untuk mendiskusikan sub-bab mereka.

d. Setelah selesai diskusi sebagai kelompok ahli, setiap anggota kelompok kembali ke kelompok asal dan bergantian mengajar teman satu tim mereka tentang sub-bab yang mereka kuasai dan setiap anggota lainnya mendengarkan dengan sungguh-sungguh.

e. Setiap kelompok ahli mempresentasikan hasil diskusinya.

f. Guru memberikan kesimpulan, mengevaluasi, mengapresiasi, dan memberikan tindak lanjut.

g. Penutup.

Prosedur penelitian menggunakan prosedur alur dari Model Elliot (dikutip Atmono, 2009).

Berikut ini merupakan gambaran dari prosedur alur Model Elliot.

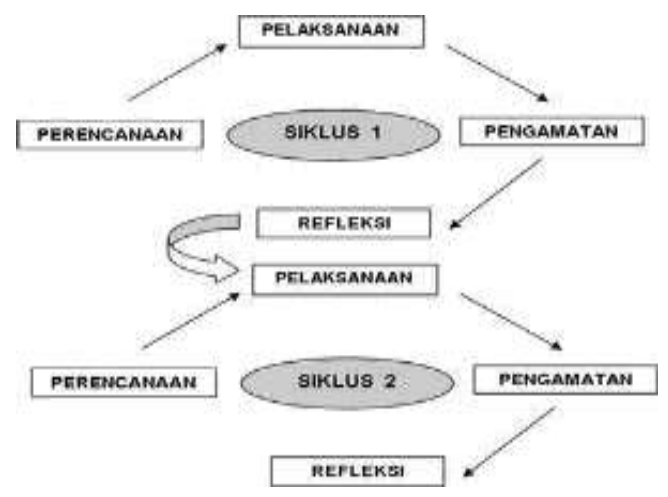

Gambar 1. Alur Penelitian Tindakan Kelas Model Elliot 


\section{JURNAL ILMIAH \\ BINA EDUKASI \\ ISSN 1979-8598 E-ISSN: 2655-8378 \\ http://journal.binadarma.ac.id/index.php/jurnalbinaedukasi \\ Vol. 13, No. 1, Juni 2020, 16 -- 26}

Setiap siklus mencakup empat tahapan, yaitu (a) perencanaan (planning), (b) pelaksanaan tindakan (action), (c) pengamatan (observasi), dan (d) refleksi dan (reflection). Empat langkah utama yang saling berkaitan itu dalam pelaksanaannya sering disebut dengan istilah satu siklus.

\subsection{Tempat Pelaksanaan Penelitian}

Lokasi Penelitian adalah SDN 06 Indralaya Utara yang beralamat di Jalan Andalas Desa Parit Kecamatan Indralaya Utara Kabupaten Ogan Ilir Provinsi Sumatera Selatan.

\subsection{Subjek Penelitian}

Subjek penelitian adalah siswa Kelas VI SDN 06 Indralaya Utara yang berjumlah 30 orang. Terdiri dari 19 orang siswa laki-laki dan 11 orang siswa perempuan.

\subsection{Teknik Pengumpulan Data}

Pengumpulan data dilakukan menggunakan teknik observasi dan tes. Lembar observasi digunakan sebagai panduan dalam kegiatan pengamatan proses KBM siswa selama mnggunakan metode Jigsaw. Tes digunakan untuk mengumpulkan data hasil belajara siswa berupa nilai matematika yang diperoleh siswa sebelum dan sesudah penerapan metode pembelajaran Jigsaw. Siswa diberikan pretes, postes I, dan postes II. Tes berupa tes uraian tertulis. Soal tes yang diberikan berdasarkan materi yang sudah disampaikan. Hasil belajar siswa diukur berdasarkan bukti-bukti yang didapat dari hasil observasi dan hasil tes yang diperoleh siswa.

\subsection{Teknik Analisis Data}

Teknik analisis data menggunakan rumus teknik proporsi (Sudjana, 2010), yaitu sebagai berikut.

$$
D=\frac{A}{N} \times 100 \%
$$

Keterangan:

D: Prosentase siswa yang tuntas

A: Jumlah siswa yang tuntas

$\mathrm{N}$ : Jumlah seluruh siswa

Hasil analisis data disajikan dalam bentuk tabel dan grafik untuk memudahkan dalam membaca data dan memprediksi penarikan kesimpulan dari penelitian yang dilakukan. Indikator keberhasilan dalam penelitian ini adalah jika $\leq 70 \%$ siswa kelas VI SDN 06 Indralaya Utara memperoleh nilai $\leq K K M 65$ untuk materi yang diajarkan. Persentase keberhasilan pencapaian hasil belajar siswa tersebut ditentukan dengan acuan dari Fatimah (2008) sebagai berikut. 
BINA EDUKASI

ISSN 1979-8598 E-ISSN: 2655-8378

http://journal.binadarma.ac.id/index.php/jurnalbinaedukasi

Vol. 13, No. 1, Juni 2020, 16 -- 26

Tabel 1. Indikator Keberhasilan Nilai Akhir Siswa

\begin{tabular}{lll}
\hline No. & \multicolumn{1}{c}{ Prosentase Ketuntasan } & \multicolumn{1}{c}{ Katagori } \\
\hline 1 & $\ldots \ldots \geq 80 \%$ & Sangat tinggi \\
2 & $70 \%-79 \%$ & Tinggi \\
3 & $60 \%-69 \%$ & Cukup \\
4 & $50 \%-59 \%$ & Kurang \\
5 & $\ldots \ldots \leq 49 \%$ & Sangat kurang \\
\hline
\end{tabular}

Teknik analisis data menggunakan teknik proporsi (Sudjana, 2010) diawali dengan kegiatan penskoran terhadap jawaban tes siswa. Penskoran jawaban siswa dilakukan menggunakan rumus berikut.

$$
D=\frac{X}{N} \times 100 \%
$$

Keterangan:

$\mathrm{D}:$ Prosentase hasil belajar siswa

$\mathrm{X}$ : Jumlah siswa yang Tuntas

$\mathrm{N}$ : Jumlah seluruh siswa

\section{HASIL DAN PEMBAHASAN}

\subsection{Hasil Penelitian}

Hasil penelitian berasal dari hasil tes dan hasil pengamatan. Hasil tes disajikan dalam bentuk data kuantitatif sedangkan hasil penelitian nontes berupa hasil observasi disajikan dalam bentuk deskriptif. Penelitian ini bertujuan untuk meningkatkan motivasi dan hasil belajar siswa dengan penerapan metode diskusi. Setiap siswa dituntut untuk mendapatkan hasil yang terbaik dan mampu mengamalkannya dalam kehidupan sehari-hari. Sehingga hasil belajar tidak hilang begitu saja ketika proses pembelajaran selesai, tetapi dapat bertahan dan digunakan ketika diperlukan. Hasil nilai rata-rata pretes, post test pada siklus I dan II dapat dilihat pada gambar berikut. 
ISSN 1979-8598 E-ISSN: 2655-8378

http://journal.binadarma.ac.id/index.php/jurnalbinaedukasi

Vol. 13, No. 1, Juni 2020, 16 -- 26

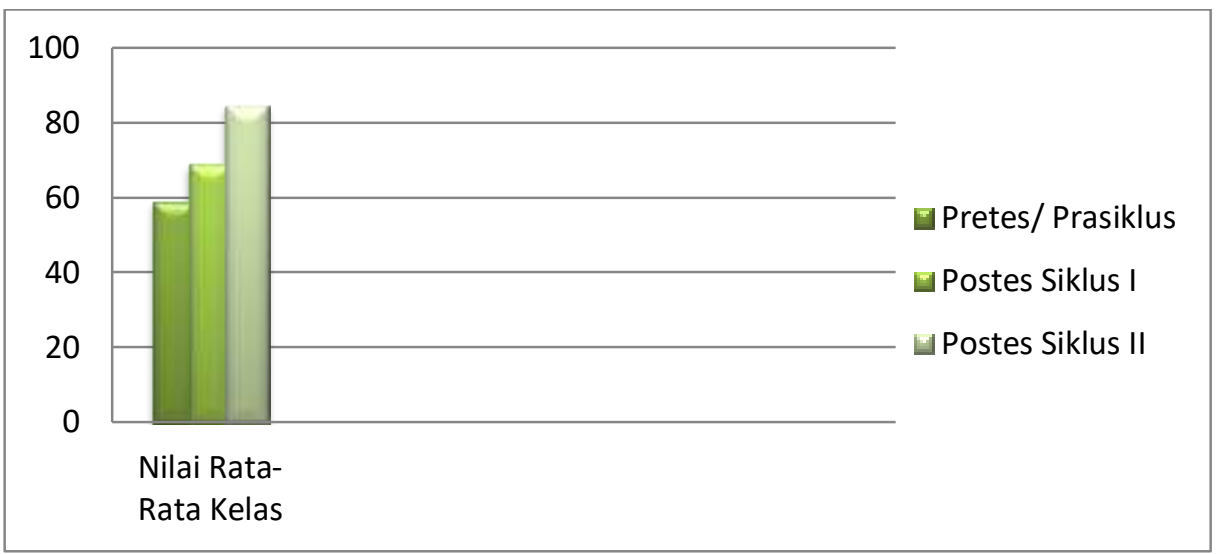

Gambar 2. Grafik nilai rata-rata kelas

Dari keterangan gambar grafik di atas dapat diketahui bahwa hasil belajar siswa Kelas VI SDN 06 Indralaya Utara pada pelajaran Matematika dapat ditingkatkan dengan penerapan metode pembelajaran Jigsaw. Pada grafik 1 tersebut terlihat bahwa ada peningkatan nilai rata-rata kelas yang signifikan dari pretes ke post test. Pada prasiklus nilai rata-rata kelas sebesar 59,00\%. Lalu pada siklus I nilai rata-rata kelas sebesar $69,00 \%$. Pada siklus II nilai rata-rata meningkat sebesar 84,6\%. Masing-masing dari prasiklus ke siklus I terjadi peningkatan sebesar 10\%. Dari siklus I ke siklus II terjadi peningkatan sebesar 15,6\%. Penelitian ini dicukupkan pada Siklus II karena hasil evaluasi pada siklus kedua sudah mencapai keberhasilan dengan kategori "Cukup Tinggi" dengan persentase siswa yang mencapai nilai KKM 65 sebesar $70 \%$ dan telah mencapai target ketuntasan yang telah ditetapkan.Berdasarkan hasil tersebut berarti hasil penelitian ini sudah mencapai indikator yang ditentukan yaitu $70 \%$ dan peneliti tidak melanjutkan penelitian ke siklus berikutnya. Selain hasil nilai rata-rata, hasil persentase tersebut terlihat pada tabel di bawah ini.

Tabel 2. Persentase Ketuntasan Nilai KKM Siswa

\begin{tabular}{ccc}
\hline Tahapan Tes & Ketuntasan (\%) & Ketidaktutasan $(\boldsymbol{\%})$ \\
\hline Pra Siklus & 40,00 & 60,00 \\
Akhir Siklus I & 63,33 & 36,66 \\
Akhir Siklus II & 90,00 & 10,00 \\
\hline
\end{tabular}

Berdasarkan tabel 2 di atas, dapat dilihat hasil peningkatan ketuntasan secara klasikal siklus I terjadi peningkatan hasil belajar dari pra siklus $40,00 \%$ ke siklus I $63,33 \%$, mengalami peningkatan ke siklus II menjadi 90,00\%. Jadi pembelajaran dengan metode pembelajaran Jigsaw dinyatakan "Berhasil" karena sudah mencapai tingkat ketuntasan $\leq 70 \%$ yaitu $90,00 \%$. Peningkatan hasil belajar yang terjadi dikarenakan siswa lebih cepat mengingat materi pelajaran dengan penerapan pembelajaran metode pembelajaran Jigsaw dan proses pembelajaran 


\section{JURNAL ILMIAH \\ BINA EDUKASI \\ ISSN 1979-8598 E-ISSN: 2655-8378 \\ http://journal.binadarma.ac.id/index.php/jurnalbinaedukasi \\ Vol. 13, No. 1, Juni 2020, 16 -- 26}

disesuaikan dengan rencana pelaksanaan pembelajaran yang telah disusun. Siswa terlihat sangat terbantu dengan adanya metode pembelajaran Jigsaw.

\subsection{Pembahasan}

Dalam proses pembelajaran siswa dapat mendengar, melihat dan mencari sendiri jawaban dari permasalahan yang mereka hadapi yang akhirnya mereka dapat dengan mudah menyelesaikan permasalahan dan soal-soal yang diberikan dengan penerapan pembelajaran ini. Dengan demikian tampak bahwa penerapan metode pembelajaran Jigsaw dapat meningkatkan hasil belajar siswa pada pelajaran matematika. Secara lebih rinci dapat dilihat pada grafik berikut.

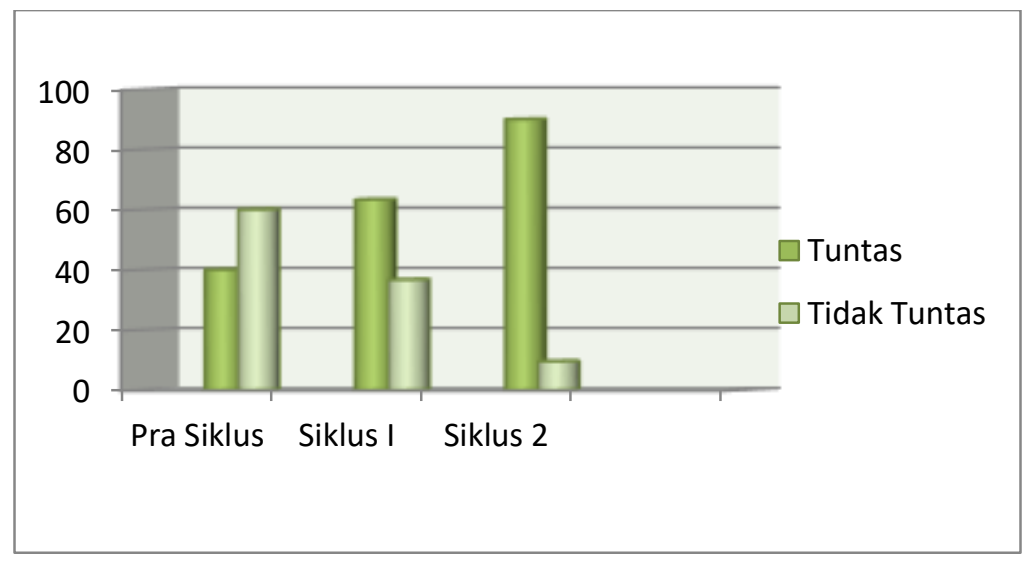

Gambar 3. Grafik Perbandingan Persentase Ketuntasan Hasil Belajar

Grafik di atas menunjukkan bahwa nilai rata-rata yang dicapai sebagai hasil belajar siswa pada siklus II lebih tinggi dibanding siklus I demikian juga dengan ketuntasan klasikalnya. Dari data pada grafik tersebut terlihat perbandingan hasil belajar yang signifikan sebelum dan sesudah penerapan metode pembelajaran Jigsaw dalam pelajaran matematika.

Berdasarkan hasil penelitian, yaitu hasil dari nilai rata-rata pada pretes, kemudian post test di siklus I dan II disimpulkan bahwa penerapan metode pembelajaran Jigsaw memberikan dampak yang signifikan terhadap hasil belajar siswa. Hal tersebut terlihat dari persentase ketuntasan KKM pada siswa kelas VI dalam pelajaran Matematika. Peningkatan hasil belajar terjadi karena guru menerapkan metode pembelajaran Jigsaw.

Peningkatan hasil belajar yang terjadi dikarenakan siswa lebih cepat mengingat materi pelajaran dengan menggunakan metode pembelajaran kooperatif tipe Jigsaw dan proses pembelajaran disesuaikan dengan rencana pelaksanaan pembelajaran yang telah disusun. Dalam proses pembelajaran ditemukan hal-hal sebagai berikut.

a. Siswa mulai berani mengemukakan pendapat pada kelompoknya karena merasa leluasa dalam berinteraksi.

b. Siswa menyampaikan gagasan yang bervariasi sehingga dalam penyelesaian masalah memerlukan waktu yang agak lama. 


\section{JURNAL ILMIAH \\ BINA EDUKASI \\ ISSN 1979-8598 E-ISSN: 2655-8378 \\ http://journal.binadarma.ac.id/index.php/jurnalbinaedukasi \\ Vol. 13, No. 1, Juni 2020, 16 -- 26}

c. Siswa sudah terbiasa dengan model pembelajaran dengan menggunakan metode pembelajaran kooperatif tipe Jigsaw, sehingga pembelajaran berlangsung sesuai dengan rencana pembelajaran.

\section{SIMPULAN}

Berdasarkan hasil penelitian dan pembahasan, peneliti menyimpulkan bahwa metode pembelajaran Jigsaw dapat meningkatkan hasil belajar Matematika siswa kelas VI SD Negeri 06 Indralaya Utara Kabupaten Ogan Ilir. Hasil penelitian menunjukkan hasil yang signifikan dari pretes ke post test siklus I dan II, yaitu dari 40,00\% ke 63,33\%. Kemudian, pada post test siklus II sebesar 90,00\%. Pada siklus II, ketuntasan belajar sudah mencapai 70\% maka PTK cukup sampai dengan Siklus II. Selain hasil belajar, penerapan metode pembelajaran Jigsaw juga meningkatkan motivasi belajar siswa, serta meningkatkan kemampuan siswa dalam berpikir kritis. Pada nilai-nilai karakter, penerapan metode pembelajaran Jigsaw juga meningkatkan sikap percaya diri, kerja sama, dan menghargai pada siswa.

Hasil penelitian ini diharapkan dapat memberikan pengetahuan dan pengalaman yang berharga bagi peneliti, guru, dan siswa. Peneliti lain juga dapat menerapkan metode ini pada mata pelajaran lain atau materi lain. Dari penelitian ini, diharapkan guru kreatif dalam merancang kegiatan belajar dengan menggunakan metode pembelajaran yang sesuai dengan materi dan kebutuhan siswa sehingga pembelajaran menjadi lebih bermakna. Pihak sekolah juga mendukung kegiatan belajar mengajar dengan menyediakan sarana dan prasarana belajar yang layak.

\section{DAFTAR PUSTAKA}

Aqib, Zainal. (2009). Penelitian Tindakan Kelas. Bandung: CV. Yrama Widya.

Atmono, Dwi. (2009). Penelitian Tindakan Kelas. Kalimantan Selatan: Scripta Cendekia.

Fatimah, Siti. (2008). Modul Model-Model Pembelajaran SMP dan SMA. Palembang: Universitas Sriwijaya.

Nana Sudjana. (2010). Dasar-Dasar Proses Belajar. Bandung: Sinar Baru Bandung.

Nasruddin dan Zainal Abidin. (2017). Meningkatkan Hasil Belajar Matematika Melalui Model Pembelajaran Kooperatif Tipe Jigsaw pada Siswa SMP. Journal of Educational Science and Technology. 3 (2), 113-121. https://ojs.unm.ac.id/JEST/article/view/3557/1981. Diunduh pada tanggal 23 Maret 2020.

Ristanti, Triana. (2017). Penerapan Model Pembelajaran Kooperatif Tipe Jigsaw untuk Meningkatkan Motivasi Belajar dan Prestasi Belajar Kompetensi Dasar Persediaan Siswa Kelas XI AK 1 SMK YPE Sawunggalih Tahun Ajaran 2016/2017. Skripsi tidak dipublikasikan. Yogyakarta: Fakultas Ekonomi, Universitas Negeri Yogyakarta.

Santoso, Imam. (2018). Peningkatan Prestasi Belajar Matematika Dengan Menggunakan Metode Pembelajaran Kooperatif Model Jigsaw. Dar El-Ilmi: Jurnal Studi Keagamaan, 


\section{JURNAL ILMIAH}

BINA EDUKASI

ISSN 1979-8598 E-ISSN: 2655-8378

http://journal.binadarma.ac.id/index.php/jurnalbinaedukasi

Vol. 13, No. 1, Juni 2020, 16 -- 26

Pendidikan, dan Humaniora. $5 \quad$ (1), $36-54 . \quad$ http://ejurnal.unisda.ac.id/index.php/dar/article/view/1080. Diunduh pada tanggal 14 Maret 2020.

Soedarsono, FX. (2001). Pedoman Pelaksanaan Penelitian Tindakan Kelas. Jakarta: Raja Grafindo Persada.

Sukardi. (2007). Metodologi Penelitian Pendidikan. Yogyakarta: Bumi Aksara. 